\begin{tabular}{|l|l|l||}
\hline \multicolumn{2}{|c|}{ PublisherInfo } \\
\hline \hline PublisherName & $:$ & BioMed Central \\
\hline \hline PublisherLocation & $:$ & London \\
\hline \hline PublisherImprintName & $:$ & BioMed Central \\
\hline \hline
\end{tabular}

\title{
Linkage analysis in yeast
}

\begin{tabular}{|l|l|l||}
\hline \multicolumn{2}{|c|}{ ArticleInfo } \\
\hline \hline ArticleID & $:$ & 4437 \\
\hline \hline ArticleDOI & $:$ & $10.1186 /$ gb-spotlight-20020402-02 \\
\hline \hline ArticleCitationID & $:$ & spotlight-20020402-02 \\
\hline \hline ArticleSequenceNumber & $:$ & 103 \\
\hline \hline ArticleCategory & $:$ & Research news \\
\hline ArticleFirstPage & $:$ & 1 \\
\hline \hline ArticleLastPage & $:$ & 2 \\
\hline \hline & & RegistrationDate : 2002-4-2 \\
\hline ArticleHistory & $:$ & OnlineDate \\
\hline \hline ArticleCopyright & $:$ & BioMed Central Ltd2002-4-2 \\
\hline \hline ArticleGrants & $:$ & \\
\hline \hline ArticleContext & $:$ & 130593311 \\
\hline \hline
\end{tabular}




\section{Jonathan B Weitzman}

Email: jonathanweitzman@hotmail.com

In a paper published on March 28 in Sciencexpress, Brem et al. describe how linkage analysis and gene expression profiling can be combined to dissect transcriptional regulatory networks in the budding yeast, Saccharomyces cerevisiae (DOI:10.1126/science.1069516). They crossed two yeast strains, a laboratory strain BY and a wild isolate RM from an Italian vineyard. Microarray analysis revealed 1528 genes expressed differentially between the two parent strains. They then used an oligonucleotide array technique to generate a genetic map with 3312 markers. The expression level of 570 genes showed linkage to at least one locus. Over 300 of these displayed parental differences in expression. Brem et al. suggest that regulatory patterns are complex and that many messages are affected by multiple loci (perhaps as many as five). They separated the results into those genes regulated by cis-acting modulators and sets of genes modulated by trans-acting loci. Thus, even single-celled organisms exhibit complex regulation of transcriptional variation that involves polygenic control.

\section{References}

1. Sciencexpress, [http://www.sciencexpress.org]

2. Direct allelic variation scanning of the yeast genome.

This PDF file was created after publication. 